\title{
Ethanol biosynthesis by fast hydrolysis of cassava bagasse using fungal amylases produced in optimized conditions
}

\author{
Bruna Escaramboni ${ }^{\mathrm{a}, *}$, Eutimio Gustavo Fernández Núñez ${ }^{\mathrm{b}}$, Ana Flavia Azevedo Carvalho ${ }^{\mathrm{a}}$, \\ Pedro de Oliva Neto ${ }^{\mathrm{a}}$
}

${ }^{a}$ Instituto de Pesquisa em Bioenergia, Departamento de Biotecnologia, Universidade Estadual Paulista "Júlio de Mesquita Filho", Campus-Assis, Avenida Dom Antônio 2100, 19806-900, Assis, SP, Brazil

b Grupo de Engenharia de Bioprocessos, Departamento de Ciências Biológicas, Universidade Estadual Paulista "Júlio de Mesquita Filho", Campus-Assis, Avenida Dom Antônio 2100, 19806-900, Assis, SP, Brazil

\section{A R T I C L E I N F O}

\section{Keywords:}

Amylase

Rhizopus oligosporus

Solid state fermentation

Cassava bagasse hydrolysate

Glucose

Ethanol production

\begin{abstract}
A B S T R A C T
The search for a renewable platform to produce high-value biochemicals and energy that are environmentally correct has been a current concern. A fast and inexpensive bioprocess for amylase production, able to hydrolyze complex residues in fermentable sugars to be used for ethanol production was developed. High titer amylase from Rhizopus oligosporus in solid state fermentation (SSF) was obtained by optimizing the medium supplementation using agro-industrial waste as substrate. Statistical experimental design and partial least square (PLS) regression were used to establish a relation between added chemical compounds and enzyme production, showing that urea was the most important nutrient. Crude amylase extract had competitive performance features giving higher productivities in starch hydrolysis than a commercial glucoamylase. The amylase produced was applied in the proportion of $15 \mathrm{U} / \mathrm{g}$ dry cassava bagasse to obtain cassava bagasse hydrolysate (CBH). More than $42 \%$ conversion in reducing sugars was achieved with an efficient $10 \mathrm{~h}$ single-step hydrolysis at $55{ }^{\circ} \mathrm{C}$ in a bioreactor. The concentrated $\mathrm{CBH}$ was subsequently used in fed batch process producing $89.2 \%$ ethanol yield. Furthermore, comparing just the cost of the raw materials sugarcane and $\mathrm{CHB}$, the latter demonstrated to be a lower-cost feedstock for ethanol fermentation.
\end{abstract}

\section{Introduction}

Bio-ethanol can be produced from various renewable feedstock such as sugarcane (Saccharum spp.), corn (Zea mays), wheat (Triticum spp.), cassava (Manihot spp.), and cellulose biomass (Baeyens et al., 2015). In addition, starchy residues hydrolysis for ethanol production is a very promising technology that can become extensively adopted at large scale (Cinelli et al., 2015). In the US, world's largest ethanol producer (USDA, 2014), corn starch has been used as source of biofuel for decades, with the use of corn grain balanced for food and feed, and ethanol production (Mumm et al., 2014).

Cassava production has been increasing annually in developing countries like Nigeria, the largest producer worldwide (FAOSTAT, 2016), and for these countries is an important source of food (Anyanwu et al., 2015). This crop constitutes a staple food in Sub-Saharan Africa, so much that 29 million tons of the annual Nigerian production are demanded as food (Anyanwu et al., 2015). Cassava shows the highest yield of carbohydrates per hectare after sugarcane and sugar beet (Beta spp.), and one of the best water-footprints especially on relatively low fertility soils, in drought conditions, requiring low agrochemical input and adapts well in all ecological zones (Okudoh et al., 2014). Advances in the use of wastes from cassava industry can contribute to the development of these countries and supply of food and other compounds to the world. Between 2000 and 2013, Africa continent was the largest cassava producer with about $54 \%$ of the production, followed by Asian with $31 \%$ and Americas with $15 \%$. The Brazilian production of cassava was the fourth largest in 2014 with 23.36 million tons (FAOSTAT, 2016), justifying the large amounts of cassava processing waste in the country.

For each 250-300 tons of cassava root processed, about 280 tons of bagasse with $85 \%$ moisture is produced (Pandey et al., 2000). Cassava bagasse is used as feed and has also been successfully assessed in the production of interest biomolecules demonstrating its fermentability as n-butanol (Lu et al., 2012), succinic acid (Shi et al., 2014), fatty acid, and neutral lipid (Chen et al., 2015). Currently, the majority of the cassava bagasse is discarded as waste, however, this residue can be

\footnotetext{
*Corresponding author at: Departamento de Biotecnologia, Universidade Estadual Paulista "Júlio de Mesquita Filho", Campus-Assis, Avenida Dom Antônio 2100, Bairro Parque Universitário, ZIP code: 19806-900, Assis, SP, Brazil.

E-mail address: bruna_escaramboni@yahoo.com.br (B. Escaramboni).
} 
considered as an excellent source of fermentation for higher-value biochemicals.

Currently, the starch hydrolysis processes employ two classes of enzymes, $\alpha$-amylase, and glucoamylase, at hydrolysis times that typically exceed $24 \mathrm{~h}$ (Białas et al., 2010; Cinelli et al., 2015). Amylases include an important enzyme class with many industrial and biotechnological applications, representing $25 \%$ of the enzymes market (Kumar et al., 2012). They belong to the class of hydrolases and catalyze the hydrolysis of starch and its derivatives, releasing various products, including progressively smaller dextrins and glucose polymers (Gupta et al., 2003).

There is a wide range of applications for the hydrolysis of starch and ethanol production, such as in the food, detergent, paper, textiles, baking, chemical, and pharmaceutical industries. (Gupta et al., 2003; Castro et al., 2010; Baeyens et al., 2015). Due to increasing demand, there is a huge interest in the discovery of enzymes with improved properties on starch degradation, as well as developing techniques that reduce the cost of production of amylolytic derivatives. Potential of fungi, such as Aspergillus and Rhizopus among others, are known to produce enzymes including amylases (Vaidya et al., 2015). Fungi are especially valued as excellent producers of enzymes of industrial interest. Rhizopus has been highlighted for being a good producer of amylases and its ability to metabolize complex mixtures of organic compounds in most organic residues (Jin et al., 2002; Peixoto-Nogueira et al., 2008; Freitas et al., 2014). In addition, Rhizopus oligosporus is considered safe, which is traditionally used in the food industry (Bourdichon et al., 2012).

Solid-state fermentation (SSF) has gained attention over the past 20 years in the development of industrial bioprocesses, due to several advantages over the conventional method of submerged fermentation, such as the particular physiology presented by fungi in this mode of cultivation and particularly due to the lower energy requirement, higher product yields, and less wastewater production with lesser risk of contamination (Barrios-González, 2012; Thomas et al., 2013).

The search for economical bioprocesses for the production of enzymes able to hydrolyze complex carbohydrates, such as the combination of starch and lignocellulosic compounds, has been a current concern. This fact is due to the need for better use of waste as a renewable platform to produce chemicals, food, and biofuels, considering that oil and its derivatives are non-renewable, and expansion of agricultural land is limited. In this context, the objective of this study was to develop a rapid and low cost bioprocess using natural, robust, and safe microorganism for the production of enzymes able to use agro-industrial residues hydrolysis to produce fermentable sugars which can be used for ethanol production or another bioprocess.

\section{Materials and methods}

\subsection{Microorganism and inoculum preparation}

Rhizopus oligosporus (CCT 3762) was obtained from Fundação Tropical de Pesquisas e Tecnologia "André Tosello", Campinas, SP, Brazil. The fungal strain was grown on potato dextrose agar (PDA) (Difco, USA) for 7 days at $30^{\circ} \mathrm{C}$. Viable spores were harvested from the culture by washing with $0.01 \%(\mathrm{v} / \mathrm{v})$ Tween 80 water solution and the spore suspension was used as inoculum for SSF.

\subsection{Solid state fermentation (SSF)}

Tests for SSF were conducted in $250 \mathrm{~mL}$ Erlenmeyer flasks containing $10 \mathrm{~g}$ of wheat bran (Moinho Nacional, Assis, SP, Brazil). To determine the effect of nutrient supplementation on amylase production was carried out in a preliminary experiment to define the concentration range to be used in the central composite design (CCD). The standard solution comprised: $9.3 \% \mathrm{w} / \mathrm{w}\left(\mathrm{NH}_{4}\right)_{2} \mathrm{SO}_{4} ; 4.75 \% \mathrm{w} / \mathrm{w}$ $\mathrm{KH}_{2} \mathrm{PO}_{4} ; 2.3 \%$ w/w urea (Soccol et al., 1994) was compared with trials
Table 1

Experimental range and levels (including star points") of each factor (nutrient concentration) in the CCD.

\begin{tabular}{llllll}
\hline Nutrient ${ }^{\mathrm{a}}$ concentration (\%, w/w) & \multicolumn{4}{l}{ Coded levels } \\
\cline { 2 - 6 } & $-1.68^{*}$ & -1 & 0 & 1 & $1.68^{*}$ \\
\hline$X_{1}$ : ammonium sulfate & 0 & 0.5 & 1.25 & 2 & 2.5 \\
$X_{2:}$ potassium phosphate & 0 & 0.25 & 0.63 & 1 & 1.25 \\
$X_{3}$ : urea & 0 & 0.25 & 0.63 & 1 & 1.25 \\
\hline
\end{tabular}

${ }^{\text {a }}$ Ammonium sulfate - $\left(\mathrm{NH}_{4}\right)_{2} \mathrm{SO}_{4}$ Pure for analysis -American Chemical Society (P.A.A.C.S.) (Catalog number: 01S1051.01.AH, Synth, Brazil); Monobasic potassium phosphate $-\mathrm{KH}_{2} \mathrm{PO}_{4}$ P.A. (Catalog number: 01F2002.01.AG, Synth, Brazil); Urea P.A. (Catalog number: 01U1001.01.AH, Synth, Brazil).

without supplementation and intermediate concentrations. The substrates were prepared with $60 \%$ moisture content, sterilized at $121{ }^{\circ} \mathrm{C}$ for $20 \mathrm{~min}$, inoculated with $1.10^{6}$ spores per gram of dry substrate and incubated at $30 \pm 0.5^{\circ} \mathrm{C}$ (Fanem Ltda Mod.002 CB, São Paulo, Brazil) for $120 \mathrm{~h}$ (Escaramboni and Oliva-Neto, 2014). The amylase was extracted from the fermented substrates with $5 \mathrm{~mL} / \mathrm{g}$ distilled water at $30{ }^{\circ} \mathrm{C}$ on an orbital shaker (Tecnal TE-421, São Paulo State, Brazil) at $180 \mathrm{rpm}$ for $30 \mathrm{~min}$. The enzymatic extract was separated by filtration and used for amylase activity assay.

\subsection{Central composite design (CCD)}

Response surface methodology (RSM) was used to determine the mutual interactions among the selected variables and their corresponding optimum concentrations for maximizing the amylase production. Three variables $\left(X_{1}\right.$ : ammonium sulfate; $X_{2}$ : monobasic potassium phosphate; and $X_{3}$ : urea) were analyzed. A CCD having five coded levels $(-1.68,-1,0,+1,+1.68)$, eight points associated to $2^{3}$ factorial design, six axial points and three replicates at the center point with a total number of 17 runs was formulated. The experimental range and the levels of each variable are summarized in Table 1.

The second-order polynomial model equation was fit for response variables, $y$ (amylase activity, $\mathrm{U} / \mathrm{g}$ ), was given below:

$y=\beta_{0}+\sum \beta_{i} x_{i}+\sum \beta_{i i} x_{i}^{2}+\sum \beta_{i j} x_{i} x_{j}$

where $y$ is the predicted response, $\beta_{0}$ is the offset term, $\beta_{i}$ the linear coefficients, $\beta_{i i}$ the quadratic coefficients and $\beta i j$ the interaction effect. The optimum levels of variables for maximal amylase production were obtained by analysis the response surface and contour plots.

\subsection{Statistical analysis}

The statistical software STATISTICA 8.0 trial version software (Statsoft Inc., Tulsa, OK, USA) was used to define CCD experimental design as well as analyze statistically the derived data and fit polynomial model for response variable under consideration (amylase activity). Means multiple comparisons in other experiments were performed by ANOVA and subsequently Tukey test (if necessary) in BioEstat 5.0 free software (Mamirauá Institute, Tefé, AM, Brazil).

\subsection{Analytical methods}

Amylase activity was determined using $0.5 \%(\mathrm{w} / \mathrm{v})$ soluble starch (Sigma-Aldrich, USA) as substrate in $0.05 \mathrm{M}$ sodium acetate buffer, $\mathrm{pH}$ 5.5 as a described method previously (Bernfeld, 1955) with some modifications. The reducing sugar concentration was estimated by the 3,5-dinitrosalicylic acid (DNS) method according to Miller (1959). The reaction mixture containing $100 \mu \mathrm{L}$ of crude enzyme and $650 \mu \mathrm{L}$ of substrate was incubated for $10 \mathrm{~min}$ at $60 \pm 0.1^{\circ} \mathrm{C}$ (Marconi MA 127, Piracicaba, SP, Brazil). The reaction was stopped by adding $500 \mu \mathrm{L}$ of DNS solution followed by heating it in a boiling water bath for $5 \mathrm{~min}$, 
and cooling and diluting it with $3.75 \mathrm{~mL}$ of distilled water. The concentration of reducing sugar was measured at $540 \mathrm{~nm}$ using glucose as standard. One unit of amylase activity was defined as the amount of enzyme that releases $1 \mu \mathrm{mol}$ of reducing sugars per minute and expressed as units per gram of dry substrate (U/g). Detailed steps and equation performed to measure amylase activity are described by Barchi et al. (2016).

\subsection{PLS data analysis}

The PLS technique was used to define correlation levels between the chemical elements added in the fermentation medium, represented by a matrix $\mathrm{X}$ and the amylase activity, representing the response variable matrix $\mathrm{Y}$. The independent variables matrix $(\mathrm{X})$ included concentrations of total nitrogen (TN), organic nitrogen (ON), inorganic nitrogen (IN), total phosphorus (P), total potassium (K), and total sulfur (S), which were calculated based on different concentrations of nutrients used in experimental design to optimize the chemical composition of salt solution for wetting wheat bran. The organic nitrogen contribution provided by wheat bran was calculated considering that it contains $14 \%$ protein, according to the manufacturer's information ((Moinho Nacional, Assis, SP, Brazil)). The PLS modeling was done in SIMCA 14 demo version software (Umetrics, Umeå, Sweden).

\subsection{Enzymatic hydrolysis}

Soluble starch was mixed and gelatinized with $0.05 \mathrm{M}$ sodium acetate buffer ( $\mathrm{pH} 5.5)$ to obtain a $5 \%(\mathrm{w} / \mathrm{v})$ concentration and amylolytic crude extract from $R$. oligosporus $(1.5 \mathrm{U} / \mathrm{mL}$ starch solution) was added to the mixture and incubated at 55 or $60 \pm 0.1{ }^{\circ} \mathrm{C}$ (Marconi MA 127, Piracicaba, SP, Brazil). In another experiment, glucoamylase NS22035 from the Novozymes' cellulosic ethanol enzyme kit was reacted with $5 \%(\mathrm{w} / \mathrm{v})$ soluble starch in $0.05 \mathrm{M}$ sodium acetate buffer $(\mathrm{pH}$ $5.5)$ at $60{ }^{\circ} \mathrm{C}(1.5 \mathrm{U} / \mathrm{mL}$ starch solution). In the hydrolysis for obtaining cassava bagasse hydrolysate (CBH), the amylolytic crude extract from $R$. oligosporus obtained by solid fermentation was reacted with $1.5 \mathrm{~L}$ of $10 \%(\mathrm{w} / \mathrm{v})$ dried cassava bagasse in $0.05 \mathrm{M}$ sodium acetate buffer $(\mathrm{pH}$ $5.5)$ at $55 \pm 0.1{ }^{\circ} \mathrm{C}(1.5 \mathrm{U} / \mathrm{mL}$ starch solution) 3-L bioreactor (TECBIO-Plus, Tecnal, Piracicaba, SP, Brazil) with intermittent agitation in every $30 \mathrm{~min}$. The cassava bagasse was previously gelatinized at $80{ }^{\circ} \mathrm{C}$ per $30 \mathrm{~min}$. To study the kinetics of reducing sugar production, samples were taken at appropriate time intervals for $12 \mathrm{~h}$. The yield and productivity of glucose were calculated based on Freitas et al. (2014).

\subsection{Fermentation}

For ethanol submerged fermentation, $\mathrm{CBH}$ was concentrated at $10.8 \%(\mathrm{w} / \mathrm{v})$ of reducing sugars and supplemented with following composition of chemicals (Labsynth, Diadema SP, Brazil) according to Dorta et al. (2006) (\% w/v): $0.5 \%$ yeast extract, $0.1 \%$ ammonium sulfate, $\quad 0.114 \% \quad \mathrm{~K}_{2} \mathrm{HPO}_{4} \cdot 3 \mathrm{H}_{2} \mathrm{O}, \quad 0.024 \% \quad \mathrm{MgSO}_{4} \cdot 7 \mathrm{H}_{2} \mathrm{O}, \quad 0.0028 \%$ $\mathrm{ZnSO}_{4} \cdot 7 \mathrm{H}_{2} \mathrm{O}$ and $0.0017 \% \mathrm{MnSO}_{4} \cdot \mathrm{H}_{2} \mathrm{O}$, pH 5.0 and sterilized at $121{ }^{\circ} \mathrm{C}$ for $15 \mathrm{~min}$. The microorganism was a commercial strain of Saccharomyces cerevisiae (Fleischmann", Brazil). To start the fermentation $9 \mathrm{~g}$ (dry biomass) of yeasts was suspended in $75 \mathrm{~mL}$ distilled water in $500 \mathrm{~mL}$ Erlenmeyer flasks. The fed batch process was carried out by adding $15 \mathrm{~mL}$ of the must (semi-synthetic media with $\mathrm{CBH}$ ) at $0,1,2,3$, $4,5,6,7,8$, and $9 \mathrm{~h}$ of fermentation. The final volume of the fermentative cycle was $225 \mathrm{~mL}$. The flasks were shaken at $80 \mathrm{rpm}$ on an orbital shaker (Tecnal-TE421, São Paulo State, Brazil) at $32 \pm 0.1{ }^{\circ} \mathrm{C}$ for $12 \mathrm{~h}$. The yeasts were centrifuged (Excelsa-206 BL, Brazil) after the end of the fermentative cycle at $3000 \mathrm{rpm}$ for $20 \mathrm{~min}$. The concentration of ethanol was determined using distiller and digital densimeter (Anton Paar-DMA 4500 ME) technique. Ethanol yield was calculated using 0.6475 as the $\mathrm{w} / \mathrm{v}$ conversion factor of consumed sugar to ethanol based on the theoretical maximum yield.
Table 2

Comparison of different chemical compositions of solution for wetting solid substrate on amylase production by Rhizopus oligosporus in solid state fermentation.

\begin{tabular}{lllll}
\hline \multirow{2}{*}{ Runs } & \multicolumn{2}{l}{ Variables $(\% \mathrm{w} / \mathrm{w})$} & \multirow{2}{*}{ Amylase activity (U/g) } \\
\cline { 2 - 4 } & $\left(\mathrm{NH}_{4}\right)_{2} \mathrm{SO}_{4}$ & $\mathrm{KH}_{2} \mathrm{PO}_{4}$ & Urea & \\
\hline 1-Standard & 9.3 & 4.8 & 2.3 & $180.90 \pm 10.07 \mathrm{a}^{\mathrm{a}}$ \\
2 & 0.0 & 0.0 & 0.0 & $179.94 \pm 11.81 \mathrm{a}$ \\
3 & 5.0 & 2.5 & 2.5 & $367.61 \pm 9.68 \mathrm{~b}$ \\
4 & 2.5 & 1.25 & 1.25 & $353.92 \pm 4.26 \mathrm{~b}$ \\
5 & 2.5 & 1.25 & 2.5 & $361.86 \pm 2.71 \mathrm{~b}$ \\
\hline
\end{tabular}

${ }^{a}$ Means followed by the same letter indicate no significant differences $(\mathrm{p}>0.05)$.

\section{Results and discussion}

\subsection{Optimization of the medium composition for amylase production in SSF}

High fermentation cost limits the application of bioprocesses (Huang et al., 2013) and the potential of wastes for industrialization. About $30-40 \%$ of the production cost of the industrial enzymes is due to the growth medium (Joo and Chang, 2005). The development of an economically viable bioprocess seeks to maximum enzyme production with the lowest substrate cost. The use of agro-industrial residues as a substrate and minimum nutrients supplementation leads to a low cost bioprocess.

The amylase produced from SSF process depended on the level of salts concentration used. The intermediate level determined in this work showed better performances. The preliminary experiment to determine the optimal range of nutrient concentrations to be used in CCD indicated the differences in amylase production among standard solution (treatment 1) and other solutions under consideration (Table 2). The highest amylase production was $367 \mathrm{U} / \mathrm{g}$ (treatment 3) for intermediate values of concentration of salts $\left(\mathrm{NH}_{4}\right)_{2} \mathrm{SO}_{4}, \mathrm{KH}_{2} \mathrm{PO}_{4}$, and urea. This represents a $100 \%$ increase in enzyme activity compared with the tests using only wheat bran $(180 \mathrm{U} / \mathrm{g})$ as substrate (treatment 2$)$ and those supplemented with the maximum concentration of salt $(181 \mathrm{U} / \mathrm{g})$ from the standard solution (treatment 1 ). As the treatments 3,4 , and 5 were statistically equal in enzyme activity, the treatment with the lowest concentration of nutrients (4) was selected to define the positive axial point (1.68) for each nutrient concentration in CCD (Table 1).

The experimental design and results are represented in Table 3 . The analysis of variance (ANOVA) for the variables indicated that enzyme activity can be well described by a polynomial model with a high coefficient of determination $\left(\mathrm{r}^{2}=0.9571\right)$. This result showed an excellent correlation between independent variables and amylase activity and only $4.29 \%$ of the total variations could not be explained by the model. The statistical significance of the regression model was supported by the high F-value (29.01) with very low $p$-value $(<0.0001)$, as summarized in Tables 4 and 5 .

The significance of regression coefficients, in the equation for amylases production, was defined considering significance level of $90 \%$ $(\alpha=0.1$ ). As a result, a reduced quadratic model (Eq. (2)) in terms of coded factors was fitted:

$y=327.42+37.41 X_{3}-10.25 X_{1}^{2}-11.61 X_{2}^{2}-13.70 X_{3}^{2}-9.89 X_{2} X_{3}$

where $y$ represents amylases activity $(\mathrm{U} / \mathrm{g})$, and $X_{1}, X_{2}$, and $X_{3}$ were the coded values of the test variables ammonium sulfate, potassium phosphate, and urea concentrations, respectively. The significance of each coefficient determined by Student's $t$-test and $P$-values was demonstrated in Table 5. The statistical analysis of the model showed that each variable had a significant effect on amylase synthesis: linear term $\left(X_{3}\right)$, the interaction term $\left(X_{2} X_{3}\right)$, and all the quadratic terms $\left(X_{1}^{2}, X_{2}^{2}\right.$ and $X_{3}^{2}$ ).

The amylase enzyme synthesized by $R$. oligosporus ranged from $227.7 \mathrm{U} / \mathrm{g}$ to $361.6 \mathrm{U} / \mathrm{g}$ in the experimental design. This variation 
Table 3

Experimental design for CCD with observed and predicted amylase activity for defining nutrient supplementation influence on amylolytic enzyme production by Rhizopus oligosporus (CCT 3762) using wheat bran as substrate. The components assessed where $\left(\mathrm{NH}_{4}\right)_{2} \mathrm{SO}_{4}\left(X_{1}\right), \mathrm{KH}_{2} \mathrm{PO}_{4}\left(X_{2}\right)$, and urea $\left(X_{3}\right)$.

\begin{tabular}{|c|c|c|c|c|c|c|}
\hline \multirow[t]{2}{*}{ Runs } & \multicolumn{3}{|c|}{ Independent variables } & \multicolumn{3}{|c|}{ Amylase activity (U/g) } \\
\hline & $X_{1}$ & $X_{2}$ & $X_{3}$ & Experimental & Predicted & Absolut error ${ }^{\mathrm{a}}$ \\
\hline 1 & -1 & -1 & -1 & 244.42 & 244.56 & -0.14 \\
\hline 2 & 1 & -1 & -1 & 240.58 & 264.34 & -23.76 \\
\hline 3 & -1 & 1 & -1 & 258.38 & 244.56 & 13.82 \\
\hline 4 & 1 & 1 & -1 & 264.67 & 264.34 & 0.33 \\
\hline 5 & -1 & -1 & 1 & 328.19 & 339.16 & -10.97 \\
\hline 6 & 1 & -1 & 1 & 339.14 & 319.38 & 19.76 \\
\hline 7 & -1 & 1 & 1 & 312.31 & 339.16 & -26.85 \\
\hline 8 & 1 & 1 & 1 & 313.95 & 319.38 & -5.43 \\
\hline 9 & -1.68 & 0 & 0 & 287.94 & 298.49 & -10.55 \\
\hline 10 & 1.68 & 0 & 0 & 320.80 & 298.49 & 22.30 \\
\hline 11 & 0 & -1.68 & 0 & 318.88 & 294.65 & 24.23 \\
\hline 12 & 0 & 1.68 & 0 & 282.19 & 294.65 & -12.46 \\
\hline 13 & 0 & 0 & -1.68 & 227.72 & 225.90 & 1.81 \\
\hline 14 & 0 & 0 & 1.68 & 361.59 & 351.60 & 9.98 \\
\hline 15 & 0 & 0 & 0 & 323.81 & 327.42 & -3.61 \\
\hline 16 & 0 & 0 & 0 & 324.90 & 327.42 & -2.52 \\
\hline 17 & 0 & 0 & 0 & 331.47 & 327.42 & 4.05 \\
\hline
\end{tabular}

a Difference between experimental and predicted values by the mathematical model. Uncertainty of amylase measurement was calculated in $2 \%$.

Table 4

ANOVA analysis of the developed model for the amylase activity.

\begin{tabular}{llll}
\hline Source & Sum of squares & Degrees of freedom & Mean square \\
\hline Model & 22956.72 & 5 & 4591.34 \\
Residual & 1741.04 & 11 & 158.28 \\
Total & 24697.76 & 16 & \\
$\%$ explained variation: $93.0 \%$ & & \\
\hline
\end{tabular}

Table 5

Coefficients and test of statistical significance for the activity of amylase using coded values.

\begin{tabular}{lllll}
\hline Term & Coefficient & Standard error & $t$-value & $p$-value \\
\hline Constant & 327.42 & 7.09 & 46.18 & $<0.0001$ \\
$X_{1}$ & 5.15 & 3.33 & 1.55 & 0.1662 \\
$X_{1}{ }^{2}$ & -10.25 & 3.67 & -2.79 & 0.0268 \\
$X_{2}$ & -4.74 & 3.33 & -1.42 & 0.1980 \\
$X_{2}{ }^{2}$ & -11.61 & 3.67 & -3.16 & 0.0158 \\
$X_{3}$ & 37.41 & 3.33 & 11.23 & $<0.0001$ \\
$X_{3}{ }^{2}$ & -13.70 & 3.67 & -3.73 & 0.0073 \\
$X_{1} X_{2}$ & 0.10 & 4.35 & 0.02 & 0.9818 \\
$X_{1} X_{3}$ & 1.27 & 4.35 & 0.29 & 0.7795 \\
$X_{2} X_{3}$ & -9.89 & 4.35 & -2.27 & 0.0572 \\
\hline
\end{tabular}

reflects the need of medium optimization to obtain higher yields. In order to gain a better understanding of the effects of the significant factors on amylase production, the three dimensional response surface, and contour graphs were generated to show the interaction of each pair of medium composition, which provided an interpretation of the optimum experimental conditions (Fig. 1).

There is a strong influence of urea concentration on the response since the lowest enzymatic activity was obtained without this nutrient, and higher activities were produced with the highest urea concentration (1.25\%) (Fig. 1c and d). Therefore, the axial points of urea are the responses of maximum and minimum activity. These results are in accordance with other reports in which urea, as medium supplementation, was the best nitrogen source for the $\alpha$-amylase production by Rhizopus microsporus on SSF using cassava peel (Vijayaraghavan et al., 2011) and glucoamylase by Aspergillus sp. on SSF with wheat bran (Ellaiah et al., 2002). In the last studies cited, the authors evaluated the effect of different nitrogen sources including urea, at a fixed concentration (1\%), while in the present work was presented a design to model and optimize the concentration of urea for SSF using $R$. oligosporus in which $1.25 \%(\mathrm{w} / \mathrm{w})$ urea was the appropriate level.

The results showed the concentrations of $1.25 \%$ and $0.63 \%$ (center point conditions) for ammonium sulfate and monobasic potassium phosphate, respectively, as the best for the production of amylolytic enzymes (Fig. 1a and b). In addition, higher levels of potassium phosphate decreased amylase production (Fig. 1e and f). The observed decrease in amylase production when a high level of potassium phosphate was used (Fig. 1e and f) match with previously described. Literature reports show that the production of enzymes may be limited by the high phosphorus concentration in the culture medium, such as the case of the manganese-dependent peroxidase from Phanerochaete chrysosporium in a medium of submerged culture (Liang et al., 2012). Accordingly, a high phosphate concentration was responsible for inhibition of amylases activity of B. amyloliquefaciens (Gupta et al., 2003).

\subsection{Validation of optimal chemical composition of nutrient solution}

Maximum amylase activity (361.6 U/g) was observed in experimental treatment $14(0,0,+1.68)$ with medium containing in $\mathrm{w} / \mathrm{w}$ : $1.25 \%\left(\mathrm{NH}_{4}\right)_{2} \mathrm{SO}_{4}, 0.63 \% \mathrm{KH}_{2} \mathrm{PO}_{4}$, and $1.25 \%$ urea. The adequacy of the model was examined by an additional experiment using the derived optimal conditions. The higher predicted response was $351.6 \mathrm{U} / \mathrm{g}$ and the experimental response was $346.8 \pm 4 \mathrm{U} / \mathrm{g}$. This revealed more than $98 \%$ of the predicted value, which indicated that the generated model gave an adequate prediction. The statistical optimization for amylase production was effective in predicting the fermentation profiles as a function of different salts content with a high coefficient of determination.

As the amylase activity increased with lower concentrations of potassium phosphate, and the bioprocesses requires an economical medium with the lowest concentrations of nutrients, an experiment was conducted comparing two solutions with the following concentrations of ammonium sulfate, potassium phosphate, and urea: (1) $1.25 \%$, $0.63 \%$, and $1.25 \%$ - coded values: $(0,0,+1.68)$ and $(2) 1.25 \%$, $0.25 \%$, and $1.25 \%$ - coded values: $(0,-1,+1.68)$, in four replications.

The activity of $386.36 \pm 4.79$ was obtained on the test with the salt solution 1 and $393.00 \pm 3.47$ with the salt solution 2 . The analysis of variance showed there was no difference between the averages of salt solutions $(p>0.01)$, so the salt solution 2 with lower potassium phosphate was selected as standard. This experiment showed that is possible to obtain a large amount of amylase using a concentration range between 0.25 and $0.63 \%$ of potassium phosphate, giving versatility to the process.

Soccol et al. (1994) reported the combination of $9.3 \%(\mathrm{w} / \mathrm{w})$ $\left(\mathrm{NH}_{4}\right)_{2} \mathrm{SO}_{4}, 4.8 \% \mathrm{KH}_{2} \mathrm{PO}_{4}$, and $2.3 \%$ urea as a nutrient solution to produce $108 \mathrm{U} / \mathrm{g}$ glucoamylase using $R$. oryzae 28627 in SSF and raw cassava as substrate. In this study, reduction in these nutrients concentration of $86.6,94.8$, and $45.7 \%$, respectively, triples the enzyme activity of an extract produced by SSF with wheat bran. This fact demonstrates an inhibitory effect on the glucoamylase synthesis by $R$. oligosporus when relatively high concentrations of these salts were used, probably due to the increase in osmotic balance between the fungal cells and culture medium.

The amylase activities of crude aqueous extracts were significantly higher than the values from solid state fermentations (Peixoto-Nogueira et al., 2008; Vijayaraghavan et al., 2011) and submerged fermentations (Freitas et al., 2014; Hashemi et al., 2015) using agro-industrial wastes as substrate. These results demonstrate that the processes proposed in this work were superior to others published using bacteria or fungi as a biological agent. 
(a)
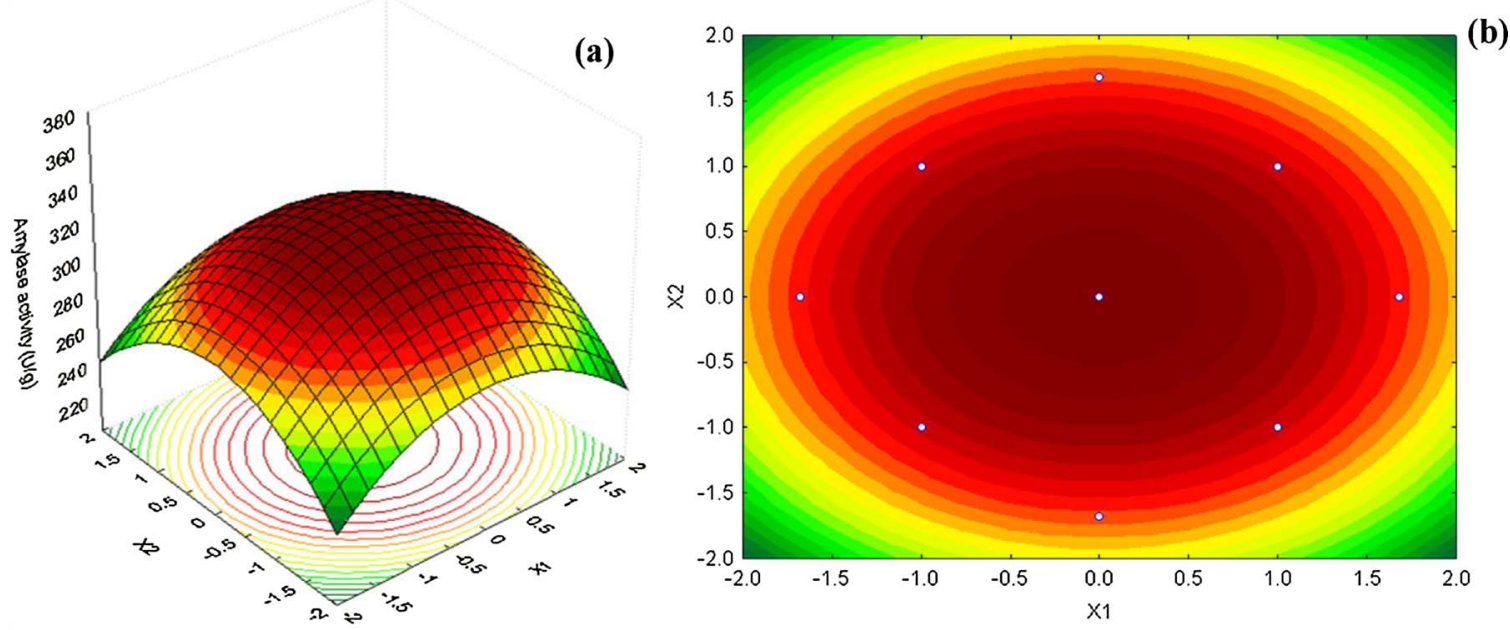

(b)

(c)
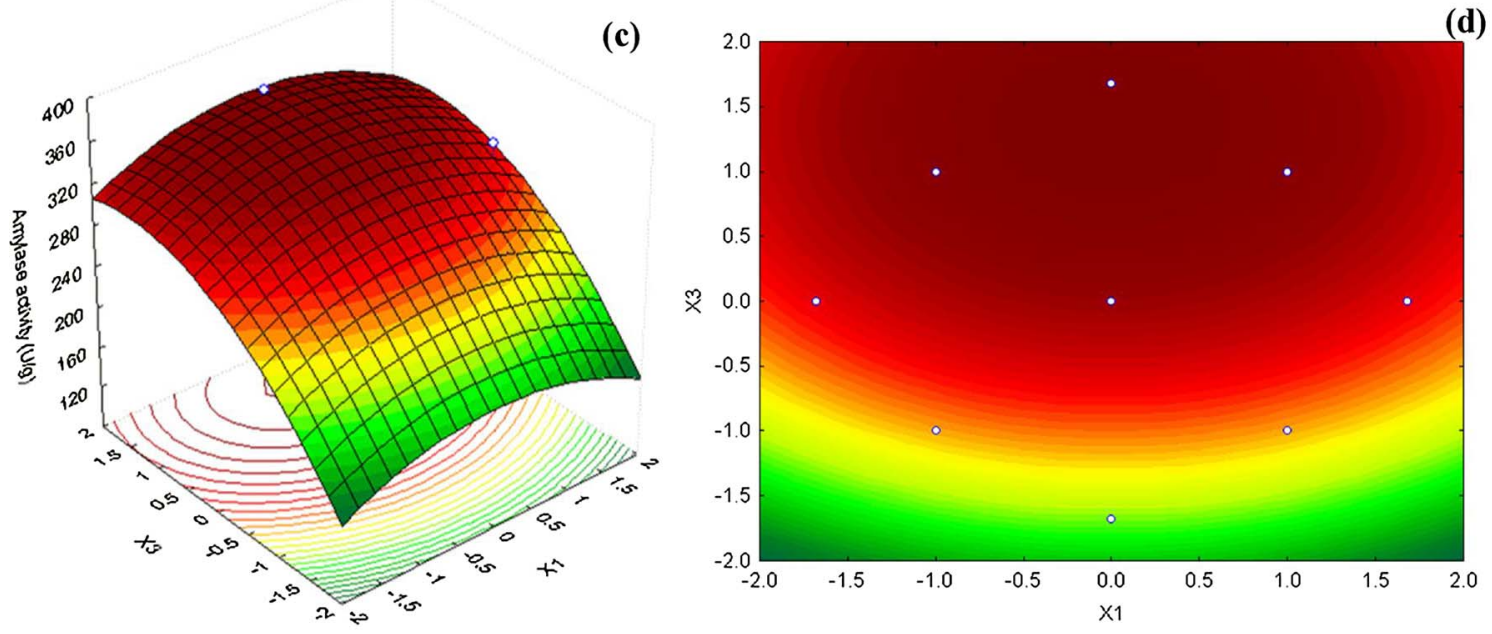

(e)

(f)
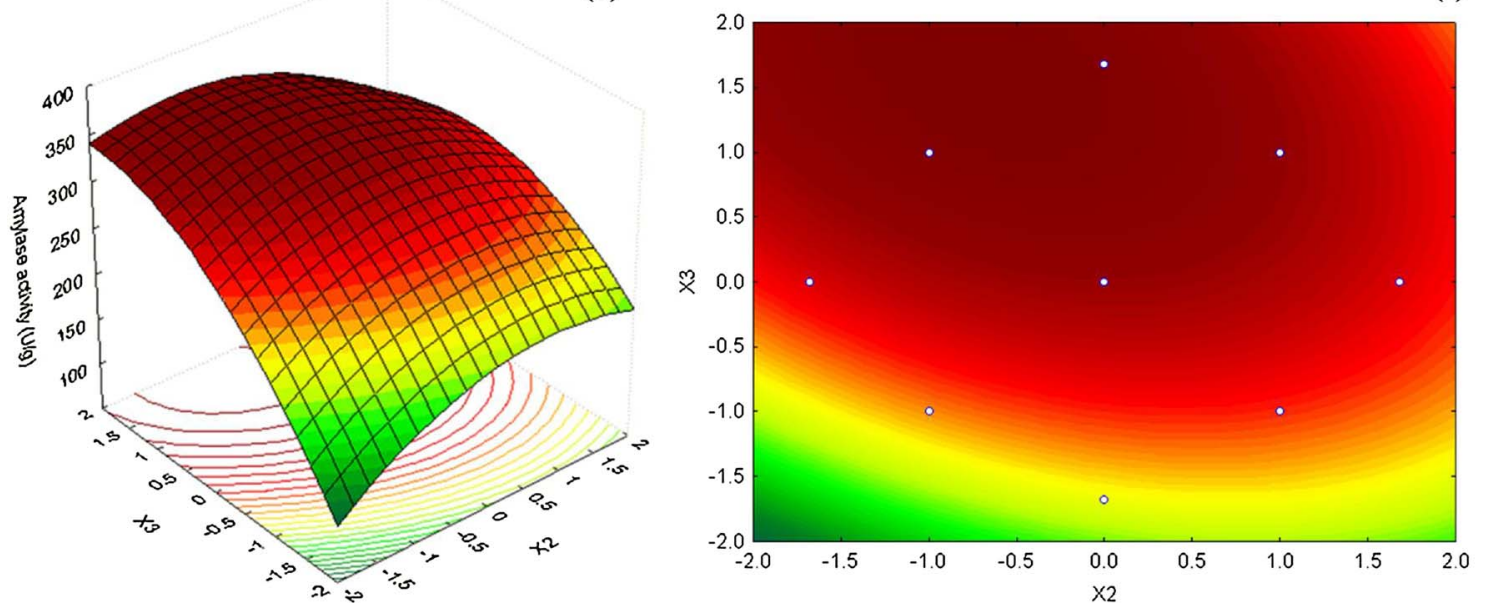

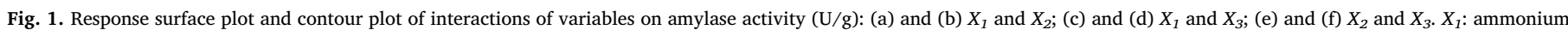
sulfate; $X_{2}$ : potassium phosphate; $X_{3}$ : urea.

\subsection{PLS data analysis}

Although partial least square (PLS) regression technique is one of the most published algorithms for multivariate calibration in different fields of knowledge, this is probably the first study which utilizes PLS to establish a relation between chemical elements in culture medium and amylase production in solid state fermentation by fungi. The choice was based on the suitability of using PLS as a tool to analyze multivariate datasets together with multiple targets (Procopio et al., 2013).

Two main components were required to satisfactorily perform modeling with a correlation coefficient of 0.89 . Due to the natural variety of biological systems, models for protozoa and fungi allow approximate predictions $(0.8124<r<0.8944)$ so that is considered suitable when the overall correlation coefficient is in the range of 0.89 . 


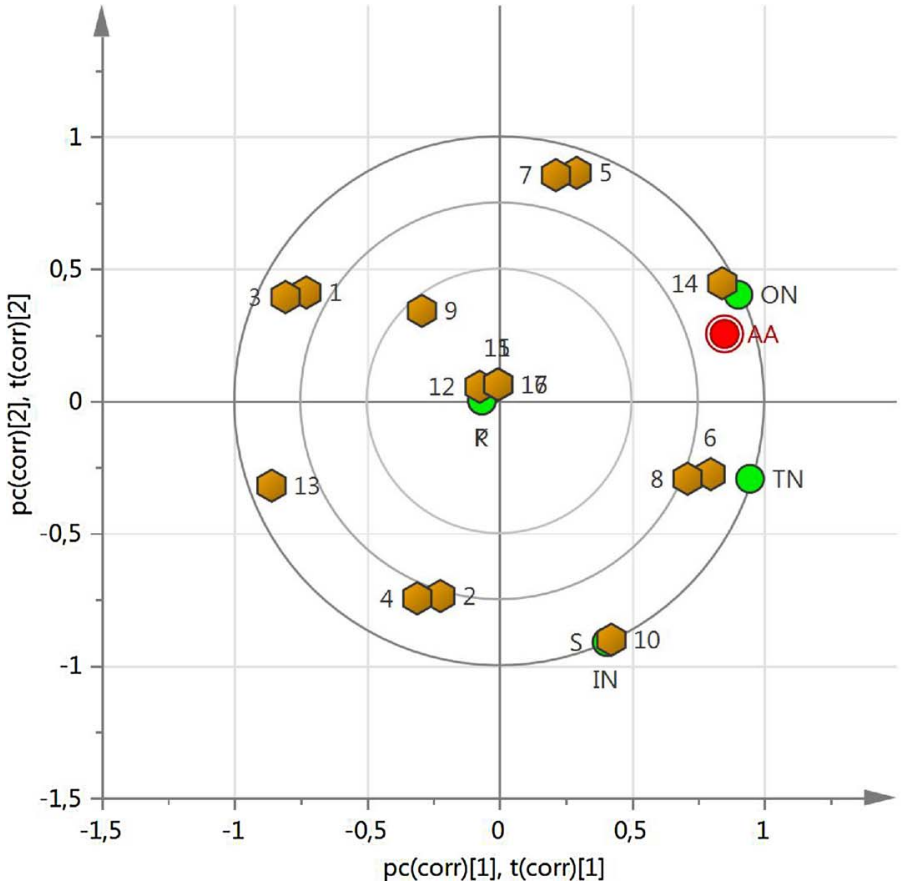

(Reeves et al., 2000; Zornoza et al., 2008).

The amylase activity was directly influenced by the organic nitrogen content added to the SSF medium as represented in Fig. 2. The increased production of amylase shows a positive correlation with the highest amount of organic nitrogen added to the medium as urea, corresponding to the trial of number 14 from experimental design (Table 3).

The statistical importance of independent variables in the model in relation to dependent variables is corroborated by the variable importance in the projection (VIP) values. The effect analysis of each nutrient added in the formulation of culture medium for $R$. oligosporus showed that inorganic nitrogen, phosphorus, and sulfur were indifferent to the expression of amylase by the fungus. Whereas the organic nitrogen content positively influences the production of this enzyme. The amount of total nitrogen was also favorable since in this experiment the sum of the amounts of organic and inorganic nitrogen was regarded (Fig. 3).

In the present work, urea showed stronger influence, followed by $\left(\mathrm{NH}_{4}\right)_{2} \mathrm{SO}_{4}$ in this enzyme expression. Different nitrogen sources lead to higher amylase expression (Kammoun et al., 2008), according to the results obtained. This supports the use of these nitrogen sources to the formulation of SSF culture medium in this work, mainly urea, as

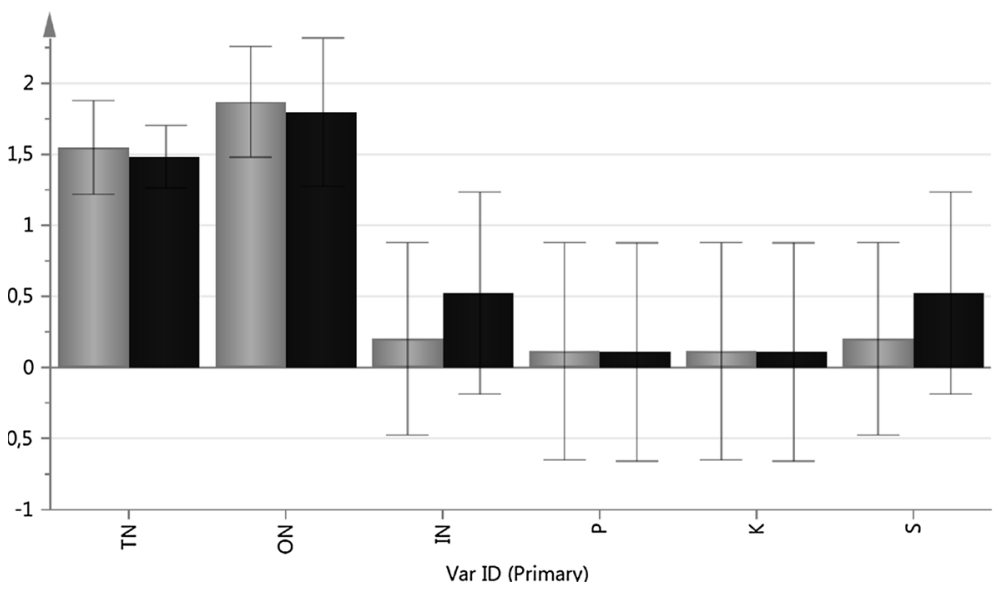

Fig. 2. Biplot graph for Nutrients-Amylase activity PLS model. Definition of model terms. $A A$ : amylase activity; $T N$ : total nitrogen; $O N$ : organic nitrogen; $I N$ : inorganic nitrogen; $P$ : total phosphorus; $K$ : total potassium; $S$ : total sulfur. Numbers represent samples included in CCD. mentioned in PLS data analysis, which is an organic nitrogen source.

\subsection{Enzymatic hydrolysis and glucose production}

Hydrolysis profile with crude amylolytic extract from $R$. oligosporus was similar in both tested temperatures. A gradual increase in conversion yield of substrates assessed for reducing sugars up to $7 \mathrm{~h}$ was observed, reaching 75.1 and $79.0 \%$ of pure starch conversion for hydrolysis at 55 and $60{ }^{\circ} \mathrm{C}$, respectively. After $11 \mathrm{~h}$ of reaction, the yield was $81.1 \%$ at $55^{\circ} \mathrm{C}$ and remained constant $(78.8 \%)$ at $60{ }^{\circ} \mathrm{C}$. In comparison, only in the first $2.5 \mathrm{~h}$, the hydrolysis profile by commercial glucoamylase at $60{ }^{\circ} \mathrm{C}$ was higher than amylase from the studied fungi, evaluated at the same temperature. After this period, the commercial enzyme had lower yields than those of the enzyme of this study ( $\mathrm{p}<0.01$ ), with a maximum yield of $75.0 \%$ after $11 \mathrm{~h}$ (Fig. 4). In addition, glucose productivity in hydrolysis using different protocols were compared and described in Fig. 5. The amylases from $R$. oligosporus showed higher productivity than commercial amylase. This fact suggests the amylases in this study are competitive with commercial amylases. The productivity of commercial glucoamylase $\left(6.2 \mathrm{~g} \mathrm{~L}^{-1} \mathrm{~h}^{-1}\right)$ was lower than amylase of $R$. oligosporus, which was 6.5 and $7.1 \mathrm{~g} \mathrm{~L}^{-1} \mathrm{~h}^{-1}$ at 55 and $60{ }^{\circ} \mathrm{C}$, respectively, in $6 \mathrm{~h}$ of reaction. 


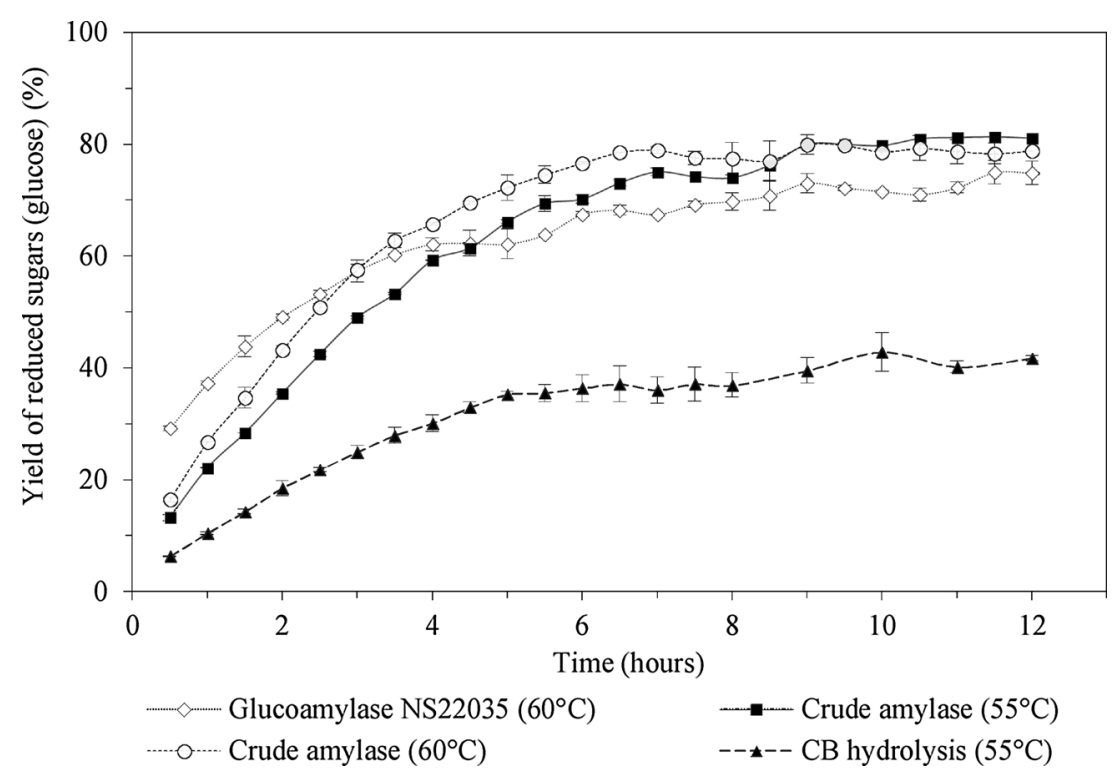

Fig. 4. Starch hydrolysis using commercial and produced amylases. $10 \%(\mathrm{w} / \mathrm{v})$ cassava bagasse (CB) hydrolysis using crude enzyme extract from Rhizopus oligosporus $(\mathbf{A}) .5 \%(\mathrm{w} / \mathrm{v})$ soluble starch hydrolysis: a comparison of crude enzyme extract from Rhizopus oligosporus at $55{ }^{\circ} \mathrm{C}(\mathbb{\square}), 60^{\circ} \mathrm{C}(\mathrm{O})$ and the commercial glucoamylase NS22035 $60{ }^{\circ} \mathrm{C}(\diamond)$. The error bars represent the standard deviations $(\mathrm{n}=3)$.
The efficiency of releasing sugars by mixing $\alpha$-amylase and glucoamylase is known to be much higher than that using only one enzyme (Chen et al., 2015). Rhizopus species are also known to produce $\alpha$ amylase and glucoamylase (Soccol et al., 1994; Han et al., 2003; Peixoto-Nogueira et al., 2008; Vijayaraghavan et al., 2011). The $R$. oligosporus strain used in this work produces glucoamylase (Del Re et al., 2003). Freitas et al. (2014) obtained just glucose as a final product during starch hydrolysis with glucoamylase produced by the same microrganism. In accordance, $R$. oligosporus has been reported as good glucoamylase producer (Jin et al., 1999; Jin et al., 2002; Freitas et al., 2014), which was purified and characterized by Kareem et al. (2011) and Kareem et al. (2014).

Freitas et al. (2014) have justified the application of $R$. oligosporus CCT 3762 amylase from submerged fermentation for the production of glucose from starch due to the high yield and product quality. The authors obtained the productivity of $9.7 \mathrm{~g} \mathrm{~L}^{-1} \mathrm{~h}^{-1}$ in $4 \mathrm{~h}$ of hydrolysis, similar to the one obtained in this work $\left(9.1 \mathrm{~g} \mathrm{~L}^{-1} \mathrm{~h}^{-1}\right)$ with the same reaction time but with amylase from solid fermentation. In addition, this enzyme showed catalytic performance competitive with commercial glucoamylase. Therefore, the use of amylolytic extract from this study suggests a simple and widely applicable method for the hydrolysis of starch residues such as bagasse cassava. According to Cinelli et al. (2015), the costs of starch-based ethanol production can be reduced if starch hydrolysis is performed at temperatures below its gelatinization temperature. In order to reduce energy demand, the temperature selected for $10 \%$ cassava bagasse hydrolysis was $55{ }^{\circ} \mathrm{C}$ since the pure starch conversion was greater than $80 \%$ using the $R$. oligosporus amylase at this temperature.

The crude amylolytic extract was used for the cassava bagasse hydrolysis and obtaining $\mathrm{CBH}$. After $6.5 \mathrm{~h}$ of reaction, $37 \%$ of the dry mass of the residue was converted into reducing sugar, reaching $42.82 \%$ after $10 \mathrm{~h}$ of reaction. Furthermore, after hydrolysis, $54.38 \%$ of the initial mass remained as solid waste from cassava bagasse. Hydrolysis yields may be different for each region since the starch content in the substrate can vary. Cassava bagasse contains about $30-50 \%$ of dry weight basis due to the processing techniques and crop varieties (Pandey et al., 2000). In spite of this, this work proposes a novel method for scaled hydrolysis of cassava bagasse in 3-L bioreactor, with which it is possible to obtain a yield of $42.82 \%$ of reducing sugars in $10 \mathrm{~h}$ of reaction using only the crude extract of $R$. oligosporus in the proportion of $15 \mathrm{U} / \mathrm{g}$ dry cassava bagasse.

The crude enzymes from $R$. oligosporus produced in the present work reached a rapid hydrolysis of cassava bagasse showing high starch conversion efficiency in glucose. The applicability of this method is supported by the absence of the need for investment in downstream steps, such as purification and concentration, and process robustness.

Among about 3000 species of plants, animals, microbes that contain cyanide, cassava is a food crop which produces cyanogenic glucosides that are stored in plant vacuoles (Gupta et al., 2010). Plants use cyanide as a defense mechanism to deter predators (Bradbury et al., 2011). High cyanide content is found in wastes as cassava peels (Ogbo, 2010) and wastewater (manipueira) (Maróstica and Pastore, 2007). Despite the

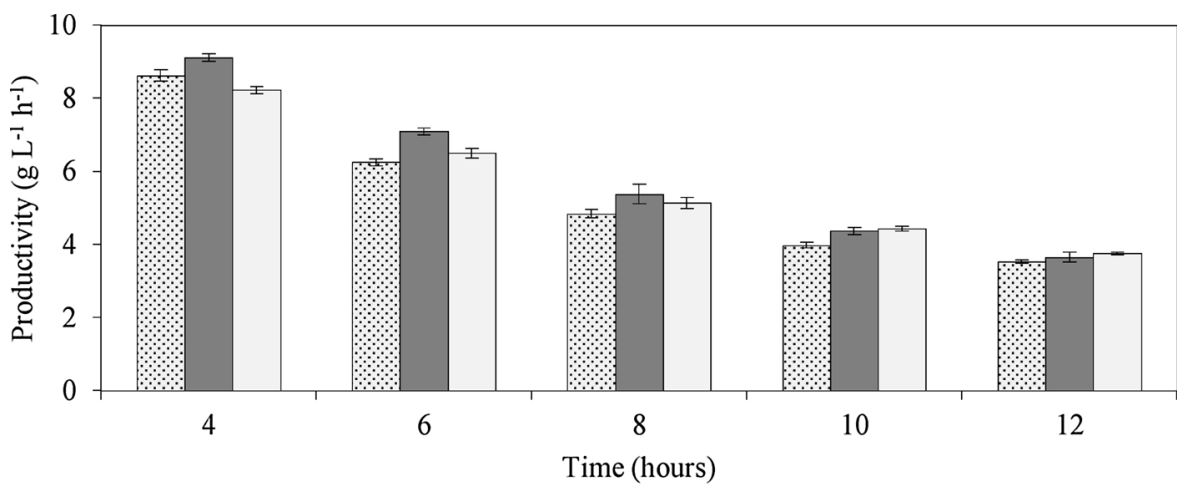

Fig. 5. Glucose productivity of starch hydrolysis: a comparison of crude enzyme extract from Rhizopus oligosporus at $55^{\circ} \mathrm{C}$ or $60^{\circ} \mathrm{C}$ and the commercial glucoamylase NS22035 at $60{ }^{\circ} \mathrm{C}$. The error bars represent the standard deviations $(\mathrm{n}=3)$.

․ Glucoamylase NS22035 $\left(60^{\circ} \mathrm{C}\right) \square$ Crude amylase $\left(60^{\circ} \mathrm{C}\right) \square$ Crude amylase $\left(55^{\circ} \mathrm{C}\right)$ 
cassava bagasse be considered free cyanide (Pandey et al., 2000) it is known that some cyanide may still remain in small proportions (Glanpracha and Annachhatre, 2016). Cyanides can be removed from industrial wastes by biodegradation, physical, and chemical methods, for example, evaporation, thermal treatment (Gupta et al., 2010), and wetting (Bradbury et al., 2011). The bioprocess proposed assures recovery and fermentability of a cassava residue even with a presence of residual cyanide. The steps of heating and evaporating the broth can eliminate by volatilization the possible presence of cyanide.

Shi et al. (2014) studied a cassava bagasse hydrolysis with three enzymes, $\alpha$-amylase ( $15 \mathrm{U} / \mathrm{g}$ ), glucoamylase (200 U/g), and cellulase, totalizing $28 \mathrm{~h}$ of reaction to achieve $45.7 \%$ of total sugars coming from the starch and cellulose. A cassava hydrolysis yield of only $16.2 \%$ expressed in percentage of reducing sugars released was obtained in $4.5 \mathrm{~h}$ of reaction using the steps of gelatinization, liquefaction with $\alpha$-amylase and saccharification with glucoamylase, and yield of 33\% when associated with cellulase in a total of $52.5 \mathrm{~h}$ (Chen et al., 2015). According to these results and considering that just one crude extract of amylases from $R$. oligosporus was used in this work, we can conclude these amylases of this strain is very efficient in starch residues hydrolysis.

\subsection{Ethanol production}

After cassava bagasse hydrolysis, $\mathrm{CBH}$ was concentrated to $10.8 \%$ $(\mathrm{w} / \mathrm{v})$ reducing sugars to be used for ethanol fermentation. Fermented must (wine) showed ethanol concentration of $3.95 \pm 0.03 \%(\mathrm{v} / \mathrm{v})$ obtained after $12 \mathrm{~h}$ of fermentation using Saccharomyces cerevisiae at $32{ }^{\circ} \mathrm{C}$. Ethanol efficiency (calculated based on consumed sugars and theoretical yield) were $89.20 \pm 0.68 \%$. In this sense, this bioprocess represents a potential production of $247.32 \mathrm{~L}$ ethanol per ton of cassava bagasse on a dry basis.

The ethanol efficiency under consideration was significantly higher than the values derived from $72 \mathrm{~h}$ of simultaneous saccharification and fermentation process using corn and cassava flour, recently published (Białas et al., 2010; Nguyen et al., 2014). In addition, Cinelli et al. (2015) reported several studies on ethanol production by starch hydrolysis of raw material from cassava and corn. They obtained a conversion efficiency of $84.6-89.6 \%$ in more than $48 \mathrm{~h}$. In the present study, there was more than $89 \%$ of the ethanol efficiency using a fast method of cassava bagasse hydrolysis in just $12 \mathrm{~h}$ fermentation, and a total period of $24 \mathrm{~h}$ for cassava bagasse hydrolysis and alcoholic fermentation. The amylolytic extract optimized in this work enables the rapid hydrolysis of starch with higher productivity than commercial glucoamylase, and conversion of complex wastes to fermentable sugars which can be used for an efficient production of ethanol.

Considering spending on raw materials, Table 6 shows the costs of producing ethanol from cassava bagasse hydrolyzed in comparison with the sugarcane. The sugarcane price (US\$20.51/ton) was calculate according to UNICA (2015) data, and for cassava bagasse, the price considered in the present work was R $\$ 100.00$ or almost US\$31.25/ton (dry basis), estimated in accordance with the traded value of the producer's milk in the Paranapanema Valley region (São Paulo State, Brazil). The value of this by-product in dry basis could be cheaper (US\$ $9.38 /$ ton) if were not increased by the transportation value (DBO, 2017). Considering just the cost of feedstock, ethanol from cassava bagasse (US\$ 0.13/L) is two times cheaper than ethanol from sugarcane (US\$ 0.26/L). In studies using only commercial amylolytic enzymes for the cassava bagasse hydrolysis, the cost of ethanol, based on the raw material price and conversion yield, was similar or higher than ethanol from sugarcane. This confirms the superiority of the treatment with amylase produced by $R$. oligosporus compared to previous studies. Similar values to the present study were reported only in treatments with commercial cellulase, $\alpha$-amylase and glucoamylase (Table 6).

Cassava root represents $83 \%$ of the costs in the tapioca starch industry (Chavalparit and Ongwandee, 2009). Therefore, the total use of this biomass received by the industry, including generated residues, is important for the industrial economy balance. In addition, the use of this agro-industrial waste as a carbon source for another process helps to solve the pollution problems. Each ton of cassava contain $211.2 \mathrm{~kg}$ of native starch and after industrial process $115.5-132.0 \mathrm{~kg}$ (Chavalparit and Ongwandee, 2009) or $150.0 \mathrm{~kg}$ (Pandey et al., 2000) is generated as solid waste. In addition, if considered the cassava bagasse generated in Brazil in 2014 (about 3.5 million tons, dry basis), it would have the potential to produce 866.6 million liters of additional ethanol, corresponding an increase of $3.04 \%$ of total ethanol production in Brazil during the same period, which was 28.48 billion liters, according to UNICA (2014).

Sugarcane is the most economical feedstock for ethanol production in the world (Baeyens et al., 2015). The ethanol price was US\$ 0.39/L in the 2014/2015 harvest in Brazil (UNICA, 2015) and also achieved similar prices in the United States (US\$ 0.37-0.45/L - New York and Chicago market) in 2015 (ANP, 2016). This value indicates that cost of feedstock accounts for $66.7 \%$ of the production cost of fuel ethanol. Cassava bagasse is a by-product of the agroindustry with low added value. Therefore, the use of this biomass as raw material to produce ethanol can be an economic alternative (Table 6). In addition, cassava was previously reported as a higher annual yield of bioethanol when compared with any other crop including sugarcane, sweet sorghum, and maize (Okudoh et al., 2014). Additionally, the processing of sugarcane results in $30 \%$ of bagasse with $50 \%$ moisture, which is used in the generation of electricity (Yadav and Solomon, 2006). In the present work, after the hydrolysis of cassava bagasse, the amount of the initial mass remained as solid waste $(54,38 \%)$, which can be used for electricity or other purposes, was a higher value than sugarcane residue.

\section{Conclusions}

This study reported a fast and economical bioprocess for the optimized production of amylases from a natural and safe microorganism

Table 6

Comparison of ethanol production costs from cassava bagasse ( $\mathrm{CB}$ - dry basis) and sugarcane considering spending on raw materials.

\begin{tabular}{|c|c|c|c|c|c|c|}
\hline Source & Hydrolysis treatment ${ }^{a}$ & Sugar $^{\mathrm{b}} \mathrm{Kg} /$ ton & Ethanol $^{\mathrm{C}} \mathrm{L} /$ ton & Source price US\$/ton & Ethanol cost US\$/L & Reference \\
\hline Cassava bagasse & Fungal amylase (crude extract) & 428.20 & 247.32 & 31.25 & 0.13 & This study \\
\hline Cassava bagasse & $\alpha$-amylase + glucoamylase & 162 & 93.57 & $31.25^{\mathrm{d}}$ & $0.33^{\mathrm{e}}$ & Chen et al. (2015) \\
\hline Cassava bagasse & Cellulase $+\alpha$-amylase + glucoamylase & 330 & 190.59 & $31.25^{\mathrm{d}}$ & $0.16^{\mathrm{e}}$ & Chen et al. (2015) \\
\hline Cassava bagasse & Cellulase $+\alpha$-amylase + glucoamylase & 457 & 263.94 & $31.25^{\mathrm{d}}$ & $0.12^{\mathrm{e}}$ & Shi et al. (2014) \\
\hline Cassava bagasse & Glucoamylase & 206 & 118.99 & $31.25^{\mathrm{d}}$ & $0.26^{\mathrm{e}}$ & Rattanachomsri et al. (2009) \\
\hline Sugarcane & - & 136.58 & 79.59 & 20.51 & 0.26 & UNICA (2015) \\
\hline
\end{tabular}

a Amylase produced by $R$. oligosporus in optimized conditions for this study and commercial enzymes for the other References.

b Calculated as the total reducing sugar for $\mathrm{CB}$ and total recoverable sugar for sugarcane.

${ }^{c}$ Calculated based on the conversion of sugar into ethanol using the coefficient 0.6475 with $89.2 \%$ yield for CB and $90 \%$ yield for sugarcane.

d The same price of CB used in this study was adopted for the calculation with reference data.

e Calculated in this study. 
using wheat bran supplemented with $1.25(\% \mathrm{w} / \mathrm{w})\left(\mathrm{NH}_{4}\right)_{2} \mathrm{SO}_{4}, 0.25(\%$ $\mathrm{w} / \mathrm{w}) \mathrm{KH}_{2} \mathrm{PO}_{4}$, and $1.25(\% \mathrm{w} / \mathrm{w})$ urea. The amylolytic complex containing glucoamylase presented competitive performance based on commercial glucoamylase. This crude extract was able to hydrolyze cassava bagasse to fermentable sugars in a fast and efficient hydrolysis. A cassava bagasse hydrolysed with high glucose content was obtained and was used as only carbon source for more economical ethanol production than sugarcane ethanol.

This work proposes a new alternative for the low cost ethanol production intercropped with food production, without any competition between them. Developing countries could work in this direction in order that, besides the starch and their derivatives to meet the demand in the food sector, the solid residue could be used to improve the fuel ethanol production, contributing to supply the demand for renewable fuels in the world.

\section{Funding}

This work was supported by Conselho Nacional de Desenvolvimento Científico e Tecnológico (CNPq, Brazil, grant number 141472/2015-4) and Fundação de Amparo à Pesquisa do Estado de São Paulo (FAPESP, SP, Brazil, grant numbers 2012/16651-8 and 2014/24188-1).

\section{Acknowledgments}

The authors would like to thank the Destilaria Água Bonita (Tarumã, SP, Brazil) for the ethanol sample analysis, Tereos Syral (Palmital, SP, Brazil) and Moinho Nacional (Assis, SP, Brazil) for donation of the starch substrates as well as PhD student Edson Marcelino Alves for his valuable support with the graphical abstract. The corresponding author acknowledges her parents, Durval and Neide, and brother, Gustavo, as inspiration to write this manuscript.

\section{References}

ANP, 2016. Agência Nacional do Petróleo, Gás Natural e Biocombustíveis. Boletim Anual de Preços 2016: preços do petróleo, gás natural e combustíveis nos mercados nacional e internacional. ANP, Rio de Janeiro. ISSN 2238-9458. http://www.anp.gov.br/ wwwanp/images/Boletim-Anual/Boletim-2016.pdf. (Accessed 15 November 2017).

Anyanwu, C.N., Ibeto, C.N., Ezeoha, S.L., Ogbuagu, N.J., 2015. Sustainability of cassava (Manihot esculenta Crantz) as industrial feedstock, energy and food crop in Nigeria Renew. Energy 81, 745-752.

Baeyens, J., Kang, Q., Appels, L., Dewil, R., Lv, Y., Tan, T., 2015. Challenges and opportunities in improving the production of bio-ethanol. Prog. Energy Combust. Sci. $47,60-88$.

Barchi, A.C., Ito, S., Escaramboni, B., Oliva-Neto, P., Herculano, R.D., Miranda, M.C.R. Passalia, F.J., Rocha, J.C., Fernández Núñez, E.G., 2016. Artificial intelligence approach based on near-infrared spectral data for monitoring of solid-state fermentation. Process Biochem. 51, 1338-1347.

Barrios-González, J., 2012. Solid-state fermentation: physiology of solid medium, its molecular basis and applications. Process Biochem. 47, 175-185.

Bernfeld, P., 1955. Methods of Enzymology. Academic Press Inc., New York, pp. 149.

Białas, W., Szymanowska, D., Grajek, W., 2010. Fuel ethanol production from granular corn starch using Saccharomyces cerevisiae in a long term repeated SSF process with full stillage recycling. Bioresour. Technol. 101, 3126-3131.

Bourdichon, F., Casaregola, S., Farrokh, C., Frisvad, J.C., Gerds, M.L., Hammes, W.P., Harnett, J., Huys, G., Laulund, S., Ouwehand, A., Powell, I.B., Prajapati, J.B., Seto, Y., Schure, E.T., Van Boven, A., Vankerckhoven, V., Zgoda, A., Tuijtelaars, S., Hansen, E.B., 2012. Food fermentations: microorganisms with technological beneficial use. Int. J. Food Microbiol. 154, 87-97.

Bradbury, J.H., Cliff, J., Denton, I.C., 2011. Uptake of wetting method in Africa to reduce cyanide poisoning and konzo from cassava. Food Chem. Toxicol. 49, 539-542.

Castro, A.M., Carvalho, D.F., Freire, D.M.G., Castilho, L.R., 2010. Economic analysis of the production of amylases and other hydrolases by Aspergillus awamori in solid-state fermentation of babassu cake. Enzyme Res. 2010.

Chavalparit, O., Ongwandee, M., 2009. Clean technology for the tapioca starch industry in Thailand. J. Clean. Prod. 17, 105-110.

Chen, J., Liu, X., Wei, D., Chen, G., 2015. High yields of fatty acid and neutral lipid production from cassava bagasse hydrolysate $(\mathrm{CBH})$ by heterotrophic Chlorella protothecoides. Bioresour. Technol. 191, 281-290.

Cinelli, B.A., Castilho, L.R., Freire, D.M.G., Castro, A.M., 2015. A brief review on the emerging technology of ethanol production by cold hydrolysis of raw starch. Fuel 150, 721-729.

DBO, 2017. Revista DBO Fevereiro 436. http://www.portaldbo.com.br/Revista-DBO/ Destaques/Massa-de-mandioca-cai-bem-no-cocho-e-no-bolso/19564. (Accessed 15
November 2017).

Del Re, G., Di Giacomo, G., Spera, L., Vegliò, F., 2003. Integrated approach in the biotreatment of starch wastes by Rhizopus oligosporus: kinetic analysis. Desalination 156, 389-396.

Dorta, C., Oliva-Neto, P., Abreu-Neto, M.S., Nicolau-Junior, N., Nagashima, A.I., 2006. Sinergism among lactic acid, sulfite, $\mathrm{pH}$ and ethanol in alcoholic fermentation of Saccharomyces cerevisiae (PE-2 and M-26). World J. Microbiol. Biotechnol. 22, 177-182.

Ellaiah, P., Adinarayana, K., Bhavani, Y., Padmaja, P., Srinivasulu, B., 2002. Optimization of process parameters for glucoamylase production under solid state fermentation by a newly isolated Aspergillus species. Process Biochem. 38, 615-620.

Escaramboni, B., Oliva-Neto, P., Processo para obtenção de xarope de glicose via hidrólise por extrato amilolítico. Brazilian Patent (2014), $\mathrm{N}^{\circ}$ BR 10-2014-031591-8. Available at: http://hdl.handle.net/11449/144565.

FAOSTAT, 2016. Food and Agriculture Organization of the United Nations. http://faostat. fao.org. (Accessed 13 September 2016).

Freitas, A.C., Escaramboni, B., Carvalho, A.F.A., Lima, V.M.G., Oliva-Neto, P., 2014 Production and application of amylases of Rhizopus oryzae and Rhizopus microsporus var. oligosporus from industrial waste in acquisition of glucose. Chem. Pap. 68, $442-450$.

Glanpracha, N., Annachhatre, A.P., 2016. Anaerobic co-digestion of cyanide containing cassava pulp with pig manure. Bioresour. Technol. 214, 112-121.

Gupta, R., Gigras, P., Mohapatra, H., Goswami, V.K., Chauhan, B., 2003. Microbial aamylases: a biotechnological perspective. Process Biochem. 38, 1599-1616.

Gupta, N., Balomajumder, C., Agarwal, V.K., 2010. Enzymatic mechanism and biochemistry for cyanide degradation: a review. J. Hazard. Mater. 176, 1-13.

Han, B.-Z., Ma, Y., Rombouts, F.M., Nout, M.J.R., 2003. Effects of temperature and relative humidity on growth and enzyme production by Actinomucor elegans and Rhizopus oligosporus during sufu pehtze preparation. Food Chem. 81, 27-34.

Hashemi, M., Shojaosadati, S.A., Razavi, S.H., Mousavi, S.M., 2015. Different catalytic behavior of $\alpha$-amylase in response to the nitrogen substance used in the production phase. J. Ind. Eng. Chem. 21, 772-778.

Huang, C., Chen, X.-F., Xiong, L., Chen, X.-D., Ma, L.-L., Chen, Y., 2013. Single cell oil production from low-cost substrates: the possibility and potential of its industrialization. Biotechnol. Adv. 31, 129-139.

Jin, B., van Leeuwen, H.J., Patel, B., Doelle, H.W., Yu, Q., 1999. Production of fungal protein and glucoamylase by Rhizopus oligosporus from starch processing wastewater. Process Biochem. 34, 59-65.

Jin, B., Yan, X.Q., Yu, Q., Van Leeuwen, J.H., 2002. A comprehensive pilot plant system for fungal biomass protein production and wastewater reclamation. Adv. Environ. Res. 6, 179-189.

Joo, H.-S., Chang, C.-S., 2005. Production of protease from a new alkalophilic Bacillus sp. I-312 grown on soybean meal: optimization and some properties. Process Biochem. 40, 1263-1270.

Kammoun, R., Naili, B., Bejar, S., 2008. Application of a statistical design to the optimization of parameters and culture medium for $\alpha$-amylase production by Aspergillus oryzae CBS 819.72 grown on gruel (wheat grinding by-product). Bioresour. Technol. 99, 5602-5609.

Kareem, S.O., Akpan, I., Popoola, T.O.S., Sanni, L.O., 2011. Activated charcoal -A potential material in glucoamylase recovery. Enzyme Res. 2011, 1-4.

Kareem, S.O., Akpan, I., Popoola, T.O.S., Sanni, L.O., 2014. Purification and characterization of thermostable glucoamylase from Rhizopus oligosporus SK5 mutant obtained through UV radiation and chemical mutagenesis. Biokemistri 26, 19-24.

Kumar, V., Sahai, V., Bisaria, V.S., 2012. Production of amylase and chlamydospores by Piriformospora indica, a root endophytic fungus. Biocatal. Agric. Biotechnol. 1 , $124-128$.

Liang, H., Gao, D.-W., Zeng, Y.-G., 2012. Effects of phosphorus concentration on the growth and enzyme production of Phanerochaete chrysosporium. Bioresour. Technol. 107, 535-538.

Lu, C., Zhao, J., Yang, S.-T., Wei, D., 2012. Fed-batch fermentation for n-butanol production from cassava bagasse hydrolysate in a fibrous bed bioreactor with continuous gas stripping. Bioresour. Technol. 104, 380-387.

Maróstica Jr., M.R., Pastore, G.M., 2007. Production of R-(+)-a-terpineol by the biotransformation of limonene from orange essential oil, using cassava waste water as medium. Food Chem. 101, 345-350.

Miller, G.L., 1959. Use of dinitrosalicylic acid reagent for determination of reducing sugar. Anal. Chem. 31, 426-428.

Mumm, R.H., Goldsmith, P.D., Rausch, K.D., Stein, H.H., 2014. Land usage attributed to corn ethanol production in the United States: sensitivity to technological advances in corn grain yield, ethanol conversion, and co-product utilization. Biotechnol. Biofuels 7,61

Nguyen, C.-N., Le, T.-M., Chu-Ky, S., 2014. Pilot scale simultaneous saccharification and fermentation at very high gravity of cassava flour for ethanol production. Ind. Crop Prod. 56, 160-165.

Ogbo, F.C., 2010. Conversion of cassava wastes for biofertilizer production using phosphate solubilizing fungi. Bioresour. Technol. 101, 4120-4124.

Okudoh, V., Trois, C., Workneh, T., Schmidt, S., 2014. The potential of cassava biomass and applicable technologies for sustainable biogas production in South Africa: a review. Renew. Sust. Energ Rev. 39, 1035-1052.

Pandey, A., Soccol, C.R., Nigam, P., Soccol, V.T., Vandenberge, L.P.S., Mohan, R., 2000 Biotechnological potential of agro-industrial residues II: Cassava bagasse. Bioresour. Technol. 74, 81-87.

Peixoto-Nogueira, S.C., Sandrim, V.C., Guimarães, L.H.S., Jorge, J.A., Terenzi, H.F., Polizeli, M.L.T.M., 2008. Evidence of thermostable amylolytic activity from Rhizopus microsporus var. rhizopodiformis using wheat bran and corncob as alternative carbon source. Bioprocess Biosyst. Eng. 31, 329-334. 
Procopio, S., Krause, D., Hofmann, T., Becker, T., 2013. Significant amino acids in aroma compound profiling during yeast fermentation analyzed by PLS regression. LWT Food Sci. Technol. 51 (2), 423-432.

Rattanachomsri, U., Tanapongpipat, S., Eurwilaichitr, L., Champreda, V., 2009. Simultaneous non-thermal saccharification of cassava pulp by multi-enzyme activity and ethanol fermentation by Candida tropicalis. J. Biosci. Bioeng. 107, 488-493.

Reeves, J., McCarty, G., Meisinger, J., 2000. Near infrared reflectance spectroscopy for the determination of biological activity in agricultural soils. J. Near Infrared Spectrosc. 8, 161-170

Shi, X., Chen, Y., Ren, H., Liu, D., Zhao, T., Zhao, N., Ying, H., 2014. Economically enhanced succinic acid fermentation from cassava bagasse hydrolysate using Corynebacterium glutamicum immobilized in porous polyurethane filler. Bioresour. Technol. 174, 190-197.

Soccol, C.R., Iloki, I., Marin, B., Raimbault, M., 1994. Comparative production of alphaamylase, glucoamylase and protein enrichment of raw and cooked cassava by Rhizopus strains in submerged and solid state fermentations. J. Food Sci. Technol. 31, 320-323.

Thomas, L., Larroche, C., Pandey, A., 2013. Current developments in solid-state fermentation. Biochem. Eng. J. 81, 146-161.

UNICA, 2014. Unicadata Brazilian Sugarcane Industry Association. Production Data
2014. http://www.unicadata.com.br/historico-de-producao-e-moagem. (Accessed 14 July 2016).

UNICA, 2015. Unicadata. Brazilian Sugarcane Industry Association. Relatório final da safra 2014/2015 Região Centro-Sul. http://www.unicadata.com.br/listagem.php? $\mathrm{idMn}=90$. (Accessed 8 October 2015).

USDA, 2014. U.S. Foreign Agricultural Service: Ethanol Exports Rebound in 2014. http:// www.fas.usda.gov/sites/default/files/2015-04/04-2015_ethanol_iatr.pdf. (Accessed 22 February 2016)

Vaidya, S., Srivastava, P.K., Rathore, P., Pandey, A.K.J., 2015. Amylases: a prospective enzyme in the field of biotechnology. J. Appl. Biosci. 41, 1-18.

Vijayaraghavan, P., Remya, C.S., Prakash Vincent, S.G., 2011. Production of $\alpha$-amylase by Rhizopus microsporus using agricultural by-products in solid state fermentation. Res. J. Microbiol. 6, 366-375.

Yadav, R.L., Solomon, S., 2006. Potential of developing sugarcane by-product based industries in India. Sugar Tech 8, 104-111.

Zornoza, R., Guerrero, C., Mataix-Solera, J., Scow, K.M., Arcenegui, V., Mataix-Beneyto, J., 2008. Near infrared spectroscopy for determination of various physical, chemical and biochemical properties in Mediterranean soils. Soil Biol. Biochem. 40, 1923-1930. 